Красинский Владислав Вячеславович, научный сотрудник НИИ проблем укрепления законности и правопорядка Генпрокуратуры Российской Федерации, кандидат юридических наук

Источник опубликования: Красинский В.В. Правовая оценка российского лоббизма // Юридический мир. М.: Юридический мир ВК, 2004. № 8-9. С. 86-89; www.krasinskiy.ru

\title{
ПРАВОВАЯ ОЦЕНКА РОССИЙСКОГО ЛОББИЗМА
}

Сегодня много пишут и говорят о лоббистской деятельности, механизмах лоббирования, необходимости законодательного регулирования лоббизма в России ${ }^{1}$. Попытаемся разобраться с этой проблематикой и ответить на ряд вопросов, имеющих непосредственное отношение к предмету исследования. В чем причина лоббизма? Почему проблема лоббизма стала в последние годы такой популярной? Кому выгодно законодательное регулирование лоббизма? Ответы, в первую очередь, надо искать в сложившейся системе воспроизводства и функционирования публичной власти.

Существующую в современной России структуру власти можно определить как «власть больших денег» с разделением функций формального представительства и реального управления. Реальное управление осуществляется экономической элитой в Центре и регионах, которую составляют представители крупного частного капитала, финансово-промышленных групп, разбогатевшие на приватизации, скупке за бесценок государственного имущества, спекулятивных экспортно-импортных и финансовых операциях. Эта категория лиц воспринимает публичную власть как эффективное средство продвижения собственных экономических интересов, сохранения и дальнейшего наращивания принадлежащих им богатств. Формальное представительство осуществляется зависимыми от указанных бизнесструктур депутатами и выборными должностными лицами. В таких условиях оптимальной формой сосуществования бизнеса и власти становится лоббизм.

Лоббизм как социально-политическое явление представляет собой сращивание органов государственной власти и управления с финансово-промышленными группами в целях принятия выгодных этим финансово-промышленным группам нормативных правовых актов, политических, административных и иных официальных решений.

Сущность лоббизма заключается в финансировании и оказании различных услуг со стороны финансово-промышленных групп конкретным представителям органов государственной власти и управления, отстаивающим интересы данных структур путем 
принятия определенных нормативных правовых актов, политических, административных и иных официальных решений. Качественной характеристикой лоббизма является то, что продвижение интересов конкретных субъектов осуществляется за счет ущемления законных интересов других субъектов (различных категорий граждан, организаций, общества и государства в целом). Другими словами, продвижение интересов экономических структур осуществляется в односторонневыгодном порядке.

Лоббизм появился в результате использования финансово-промышленными структурами аппарата государственной власти (властных полномочий) для обогащения и продвижения определенных экономических интересов на фоне отсутствия качественного кадрового отбора государственных чиновников и действенного контроля за государственными служащими, депутатами и выборными должностными лицами.

Предпосылки для корыстного использования государственного аппарата и взаимопроникновения властных и финансово-промышленных структур, как правило, формируются еще на стадии подготовки и проведения выборов. В ходе финансируемых крупным капиталом избирательных кампаний в органах государственной власти складываются различные политические группировки, выражающие те или иные корпоративные интересы. Избранные с помощью заинтересованных лиц или организаций депутаты (должностные лица) вынуждены «отрабатывать» вложенные в их избирательные кампании средства. Чаще всего это проявляется в виде принятия определенных политических решений и лоббирования «нужных» законопроектов. В том случае, если речь идет не об избираемых должностных лицах, лоббистами становятся коррумпированные государственные служащие, использующие свое должностное положение, статус государственного органа и оказывающие незаконные платные услуги в виде принятия тех или иных решений и совершения определенных действий.

Нет ничего удивительного в том, что формирование государственного аппарата по принципам дешевизны исполнителей и тесной связи руководителей с бизнесом, ведет к коррупции, обрекающей на принятие решений, не соответствующих интересам законопослушного большинства общества. Сегодняшний государственный аппарат «прозрачен» не только для частных структур, но и для потенциальных политических и военных противников нашей страны, что выводит рассматриваемую проблему на уровень необходимости защиты национальной безопасности России ${ }^{2}$. Ситуация также осложняется недостаточно действенным контролем за государственными служащими и отсутствием какого-либо контроля вообще за депутатами и выборными должностными лицами ${ }^{3}$. 
Понятие «лоббизм» - это камуфляж, красочная обертка, красивый синоним процесса сращивания властных структур с финансово-промышленными группировками. Лоббизм выгоден как коррумпированным представителям государственной власти, приобретающим материальные блага и преимущества с использованием своего должностного положения (статуса государственного органа), так и самим финансовопромышленным группировкам.

Поэтому невозможно согласиться с мнением, что «такие явления, как коррупция, не имеют к лоббизму никакого отношения» ${ }^{4}$. Фактически лоббизм и является одним из многообразных проявлений коррупции 5 .

У лоббизма и коррупции совпадают цели, субъекты, объективная и субъективная стороны деяния. Лоббизм, как и коррупция, направлен на «приватизацию» государственной власти и, в конечном счете, на разложение самостоятельного профессионального государственного аппарата. Субъектами лоббизма и преступлений коррупционной направленности являются представители органов государственной власти и органов государственного управления. Объективная сторона включает использование официальных полномочий и возможностей занимаемой должности вопреки интересам общества или государства. Что касается субъективной стороны, то коррупционная деятельность, как и лоббирование, осуществляются из корыстной или иной личной заинтересованности.

Практически лоббизм охватывается составами преступлений, предусмотренных статьями 285, 290, 291, 178 УК РФ и рядом других. С точки зрения права нет никакой разницы между взяткой должностному лицу и подкупом депутата при голосовании за «нужный» законопроект. Нет никакой разницы между злоупотреблением должностными полномочиями и корыстным использованием возможностей представителя власти в интересах какой-либо финансовой группы или промышленной корпорации.

В том случае, если лоббизм осуществляется в ущерб интересам России по заданию или под контролем иностранных государств и негосударственных организаций, то подобные деяния следует квалифицировать по совокупности составов: конкретное должностное преступление и специальная форма государственной измены - иное оказание помощи иностранному государству, иностранной организации или их представителям.

В ряде случаев могут лоббироваться и откровенно криминальные интересы. Так, в Государственной Думе выделяются определенные группы депутатов, которые систематически голосуют против принятия Федеральных законов «О борьбе с коррупцией», «О борьбе с организованной преступностью», но не предлагают 
альтернативных законопроектов. В то же время в 2000 году указанные лица приняли Постановление об амнистии, которое затронуло широкий круг лиц, осужденных в том числе за тяжкие и особо тяжкие преступления ${ }^{6}$.

Несмотря на неоднозначное, скорее негативное, отношение общества к лоббизму и отсутствие долгосрочной сбалансированной политики государства по отношению к финансово-промышленным структурам отдельные отечественные исследователи выступают за безотлагательную необходимость правового регулирования лоббистской деятельности.

В разное время были подготовлены три варианта проекта российского федерального закона о лоббизме: группой Мишина А.А. (1993 г.), Зяблюка Н.Г. (1993 г.) и Лепехина В.А. (1995-1997 гг.).

Проект руководителя рабочей группы Комитета по делам общественных объединений и религиозных организаций Государственной Думы Лепехина В.А., в отличие от законопроектов Мишина и Зяблюка, предполагал распространение регулирования лоббистской деятельности не только на российский парламент, но и на федеральные органы государственной власти. Под лоббистской деятельностью в законопроекте Лепехина В.А. «О регулировании лоббистской деятельности в федеральных органах государственной власти» понималось «взаимодействие юридических и физических лиц с федеральными органами государственной власти с целью оказания влияния на разработку и принятие указанными органами законодательных актов, административных, политических и иных решений в своих интересах или в интересах конкретных клиентов».

Ст. 6 настоящего законопроекта устанавливала ограничения на занятие лоббистской деятельностью ${ }^{7}$. Лоббистами не могли быть:

а) лица, занимающие должности в федеральных органах государственной власти;

б) назначенные или приглашенные федеральными органами государственной власти эксперты, консультанты и советники.

Лицам, занимающим должности в федеральных органах государственной власти Российской Федерации, запрещалось занятие лоббистской деятельностью - в течение 1 года после прекращения их полномочий, выхода в отставку или увольнения с указанных постов или должностей.

Лоббистами не могли быть также: граждане иностранных государств, лица без гражданства или с двойным гражданством; лица, имеющие судимость за преступления и (или) находящиеся под следствием на момент регистрации в качестве лоббистов; 
несовершеннолетние; лица, не имеющие высшего образования; недееспособные, состоящие на учете в психоневрологических учреждениях.

Статьей 7 предусматривались следующие методы лоббистской деятельности: представление в федеральные органы государственной власти информации, документов и проектов решений по вопросам, находящимся в их компетенции; участие в работе комитетов, комиссий, фракций, депутатских групп и иных структур Федерального Собрания, а также органов исполнительной власти по профилю лоббируемых вопросов; устные, письменные, телефонные, электронные и иные контакты с депутатами и должностными лицами федеральных органов государственной власти в целях продвижения своих интересов или интересов своих клиентов; организация публикаций и выступлений в средствах массовой информации в поддержку конкретных законопроектов или решений государственных органов и др.

Предусматривалась регистрация лоббистов в Министерстве юстиции России и аккредитация в соответствующих федеральных органах государственной власти.

Любопытно, что разработчики данного и других законопроектов не усмотрели в осуществлении лоббистской деятельности нарушения принципа разделения властей. Вопервых, если нельзя влиять на судей (судебную власть), то почему можно влиять на принятие решений законодательной и исполнительной власти? Во-вторых, к органам исполнительной власти относятся и правоохранительные органы со спецслужбами. Получается, что лоббисты получают возможность с выгодой вмешиваться в их законную деятельность. Думается, не нужно рассказывать, к чему может привести такое «вмешательство». Наконец, мысль о выражении интересов лоббистов и их клиентов достойна уважения, но принцип народного представительства еще никто не отменял.

Определенный интерес вызывает обращение к опыту регионального правового регулирования лоббистской деятельности. Законодательство Москвы, Республики Башкортостан, Иркутской, Калининградской, Сахалинской областей и Краснодарского края, содержит упоминания о лоббизме. В Иркутской области Малый Совет Иркутского областного совета народных депутатов своим решением от 15 декабря 1992 года № 14/6МC принимает нормативный акт «О правотворчестве и нормативных правовых актах Иркутской области», глава 7 которого посвящена регулированию лоббизма в правотворчестве области. В 1995 году нормы указанного правового акта были заимствованы законодателями Краснодарского края в Законе от 6 июня 1995 г. (в ред. от 6 апреля 1999 г.) № 7-К3 «О правотворчестве и нормативных правовых актах Краснодарского края». 
Представляется целесообразным подробней остановиться на главе 7 настоящего Закона, регулирующей лоббизм.

Статья 38 Закона устанавливает, что «лоббизм в правотворчестве края есть деятельность специально уполномоченных на то лиц по информационному взаимодействию с правотворческим органом края с целью выражения интересов соответствующих организаций в региональном правотворчестве». Если под лоббизмом понимается информационное взаимодействие, то сразу возникает вопрос: зачем такая деятельность нужна? При внесении, рассмотрении и принятии любого нормативного правового акта привлекаются соответствующие эксперты и высококвалифицированные специалисты. Для чего нужны еще и лоббисты?

Лоббистская деятельность в правотворческих органах края осуществляется через официальных представителей общественных объединений при соответствующем правотворческом органе края. Часть 4 статьи 40 Закона закрепляет, что «официальными представителями общественного объединения при правотворческом органе края не могут быть:

а) депутаты;

б) лица, находящиеся на государственной службе;

в) иностранные граждане и лица без гражданства.

Странно, что в указанном перечне нет лиц, признанных судом недееспособными, ограниченно дееспособными или содержащихся в местах лишения свободы по приговору суда, бипатридов, несовершеннолетних граждан Российской Федерации, прокуроров и судей. Ограничения, заложенные в законе, не исключают ситуацию, при которой иностранные граждане, апатриды, иностранные и международные организации могут легально лоббировать свои интересы через российские общественные объединения и их представителей.

Статья 42 Закона устанавливает равный правовой статус лоббистов. Каким образом будет обеспечиваться это равноправие? Очевидно, что преимущества приобретут «толстые кошельки», а никак не «официальные представители, аккредитованные от общественных объединений инвалидов, престарелых, ветеранов войны и труда», для которых «бесплатно размножаются документы». Обеспеченным лоббистам такая привилегия, любезно предоставленная законодателем, и не нужна.

К достоинствам Закона можно отнести перечисление противоправных форм лоббизма в правотворческих органах: нарушение порядка финансирования правотворческих работ; заключение договоров на подготовку нормативных правовых актов без согласия Законодательного собрания края с организациями, учредителями 
(соучредителями) которых являются депутаты Законодательного собрания; оказание депутатами и государственными служащими правотворческих органов платных информационных услуг посредством передачи авторских проектов нормативных и иных правовых актов или их частей на любых носителях информации; оказание противоправного воздействия на депутата Законодательного собрания и членов его семьи с целью принуждения депутата к голосованию и др.

Между тем, устанавливая запрет на осуществление ряда лоббистских действий, законодатель самим фактом принятия такого закона, тем не менее, создает правовую основу для вмешательства лоббистов в правотворческий процесс. Думается все же, что использование нормативного правового регулирования для регламентации лоббизма является преждевременным.

С помощью норм права и тем более законодательно регулировать лоббизм нельзя. С одной стороны, принятие соответствующего федерального закона (нормативного акта) выглядит очень заманчиво, и цели при этом ставятся благие: «существенно снизить уровень криминализации процесса взаимодействия представителей различных групп интересов с представителями власти, обеспечить гласность и открытость принятия важнейших государственных решений» ${ }^{8}$.

Однако если узаконить взяточничество, то все поставленные цели и будут достигнуты. Давайте, в таком случае легитимируем и другие преступления коррупционной направленности. А потом пойдем дальше и узаконим «теневую юстицию» - осуществление правосудия при посредничестве организованных преступных групп.

Следует, наконец, расставить все точки над «і». Легализация лоббизма - это официальное признание государством своей неспособности противостоять коррупции. Вопрос о легализации лоббизма стоит в одном ряду с дискуссиями о легализации наркотиков, проституции и др.

Лоббистская деятельность противоречит правовым ограничениям статуса депутатов и государственных служащих, установленным частью 3 статьи 97 Конституции Российской Федерации, пунктами «в» и «г» части 2 статьи 6 Федерального закона «О статусе члена Совета Федерации и статусе депутата Государственной Думы Федерального Собрания Российской Федерации», пунктами 2 и 3 статьи 12, пунктом 4 статьи 18 Федерального закона «Об общих принципах организации законодательных (представительных) и исполнительных органов государственной власти субъектов Российской Федерации».

Скажем прямо. Нормативное правовое регулирование лоббизма по сути будет означать узаконение той порочной практики «отрабатывания» вложенных в выборы денег, 
которая сложилась в представительных органах власти. Лоббизм дискредитирует и сам правотворческий процесс.

Легализация лоббизма еще более усугубит отчуждение власти от общества. В случае легализации лоббизма будут приниматься законы, не отражающие потребности всего населения. Право станет играть не столько роль регулятора общественных отношений, сколько роль «сервиса», сферы услуг. Большинству членов общества будут навязываться решения, фактически принятые той или иной корпоративной группой. Лоббисты будут продвигать свои личные интересы, а не государственные или общественные. В этих условиях о выражении и отстаивании интересов народа, социально ориентированном политическом курсе вести речь представляется затруднительным.

Кому же выгодно законодательное регулирование лоббизма?

В первую очередь, это выгодно крупнейшим финансово-промышленным группам, криминальным бизнесструктурам и представляющим их интересы государственным чиновникам. Во-вторых, среди тех представителей правовой и политической мысли, которые постоянно муссируют проблему лоббизма, есть люди, сознательно манипулирующие общественным мнением, пытающиеся внедрить в общественное сознание идеи о том, что «лоббизм - это хорошо», «лоббизм нужен», «давайте узаконим лоббизм». При этом предпринимаются усилия апеллировать к зарубежному, преимущественно, американскому опыту9 .

Но неужели никогда не прекратятся попытки безоглядного, механического заимствования и копирования чуждого нам англосаксонского опыта? Чего стоит только неподдельная заинтересованность Государственного Департамента США в разработке и принятии российского УПК, в результате которой были введены чуждые отечественному уголовному процессу американские институты судопроизводства (сделка о признании, ориентация только на договоренность сторон и др.), а наиболее активные юристыразработчики получили американские государственные награды.

Сегодня ставится другая цель: путем внедрения института лоббизма в теорию и практику организации государственной власти трансформировать политическую (а затем и экономическую) систему Российского государства по усмотрению Запада. Благо, финансовых рычагов у заинтересованных иностранных государств для этого предостаточно. Не случайно американская глобальная система ... «широко полагается на косвенное использование влияния на зависимые иностранные элиты, одновременно извлекая значительную выгоду из притягательности своих демократических принципов и институтов» ${ }^{10}$. 
Если же посмотреть на все с другого ракурса, то проблема была и остается не в лоббизме, а в тех депутатах и должностных лицах, которых мы выбираем. Давайте перестанем выбирать бандитов, крупных финансистов, фабрикантов, бизнесменов. Отдадим предпочтение профессионалам-юристам, которые будут трудиться в представительных органах власти на общее благо. Давайте повысим уровень оплаты труда и статус государственных служащих, вынужденных направлять свою энергию на поиск заработков. Тогда и вопрос о лоббизме автоматически снимается.

Как представляется, создание условий для недопущения легализации коррупционных деяний лоббистской направленности должно осуществляться на основе реализации следующих мер:

1. Обращение уполномоченных органов в конституционные (уставные) суды субъектов Российской Федерации с представлением о проверке соответствия Конституции и федеральным законам нормативных правовых актов субъектов Российской Федерации, содержащих положения о лоббистской деятельности;

2. Повышение денежного содержания государственным служащим;

3. Совершенствование государственного и общественного контроля за деятельностью системы органов государственной власти:

4. Дополнить Федеральный закон от 5 июля 1999 года № 133-Ф3 (с изм. от 4 августа 2001 года) «О статусе члена Совета Федерации и статусе депутата Государственной Думы Федерального Собрания Российской Федерации» статьей $9^{1}$ следующего содержания:

«Член Совета Федерации, депутат Государственной Думы Федерального Собрания Российской Федерации не может использовать свои полномочия в целях оказания влияния на разработку и принятие Федеральным Собранием Российской Федерации законодательных актов, административных, политических и иных решений в личных интересах или в интересах конкретных клиентов».

5. Дополнить Уголовный кодекс Российской Федерации статьей $286^{1}$ следующего содержания:

«Статья $286^{1}$. Лоббизм

1. Лоббизм - то есть деятельность по оказанию влияния на разработку и принятие органами государственной власти нормативных и иных правовых актов, административных, политических и иных решений в интересах конкретных клиентов, осуществляемая представителями органов государственной власти с использованием своих должностных полномочий, повлекшая за собой нарушение прав и законных 
интересов граждан или организаций либо охраняемых законом интересов общества или государства, -

наказывается штрафом в размере от семисот до двух тысяч минимальных размеров оплаты труда и лишением права занимать определенные должности или заниматься определенной деятельностью на срок от трех до пяти лет, либо лишением свободы на срок до пяти лет;

2. То же деяние, совершенное:

а) организованной группой;

б) по заданию российских финансово-промышленных групп;

в) по заданию иностранных государств или организаций, -

наказывается лишением свободы на срок от десяти до пятнадцати лет».

${ }^{1}$ См.: Любимов А.П. Гражданский лоббизм: Процедуры и технологии обращений граждан. М., 1998; Любимов А.П. Профессиональный лоббизм: Технологии лоббирования. М., 1998; Любимов А.П. Лоббизм как конституционно-правовой институт. М., 1998; Павлов В. Лоббистскую деятельность - в рамки закона // Рос. юстиция. 1998. № 9. С. 22-24 и др.

${ }^{2}$ См.: Дамаскин O.B. Национальная безопасность в условиях глобализации: угрозы и противодействие. Спб., 2003. С. 97.

3 Безответственности депутатов и выборных должностных лиц способствует наделение иммунитетами, серьезно затрудняющими осуществление в отношении этой категории лиц оперативно-розыскной и уголовно-процессуальной деятельности. На федеральном уровне отсутствует право отзыва и наказов указанным лицам.

См.: Киселев K.B. Лоббизм: проблемы правового регулирования // ЧиновникЪ.uapa.ru. 2000. № 3.

5 Автор придерживается точки зрения Долговой А.И., которая полагает, что коррупция представляет собой социальное явление, характеризующееся подкупомпродажностью государственных и иных служащих и на этой основе корыстным использованием ими в личных либо узкогрупповых, корпоративных интересах официальных служебных полномочий, связанных с ними авторитета и возможностей». См.: Криминология. Под ред. А.И. Долговой. М., 1999.

6 См.: Организованная преступность, миграция, политика. М.: Российская криминологическая ассоциация, 2002. С.79.

7 См.: Механизм регулирования лоббистской деятельности в современной России: Материалы «круглого стола» // Государство и право. 1998. № 1. С. 106-111.

${ }^{8}$ Там же. С. $100,101$.

9 В настоящее время законодательное регулирование лоббизма существует в США, Канаде, Австралии и Бразилии.

10 См.: Бжезинский 3. Великая шахматная доска. Господство Америки и его геостратегические императивы. М.: Международные отношения, 1998. С. 37. 